\title{
FÍKİR VE SANAT ESERLERİ KANUNU'NA GÖRE ESER DIŞINDA KORUMA KONULARI
}

\author{
Arş. Gör. Hüseyin Cem ÇÖL*
}

\section{GiRiş}

Fikir ve Sanat Eserleri Kanunu'nun amacı, fikri yaratıcılı̆̆ın ürünü sayılan eseri ve dolayısıyla eser sahibini korumaktır. Bununla birlikte, kanun koyucu eser sayılmayan ancak eserle yakın ilişkileri bulunan bazı konuları da koruma altına almıştır. FSEK'nun, Altıncı Bölümü'nün 'Çeşitli Hükümler' başlığı altında, fikir ve sanat eserleriyle benzerlikler gösteren bazı konular düzenlenmiştir. Ancak eser dışındaki koruma konularının birbirinden çok değişik olmaları, bunların kendi aralarında uyumlu bir düzenlemeye gidilmesine elverişli olmamaktadır. Kanundaki sıralamaya göre, 'bir eserin adı, alâmetleri ve çoğaltılmış nüshalarının şekilleri' FSEK m.83'de, 'işaret, resim veya ses nakline yarayan araçlar' FSEK m.84'de, 'mektup, hatıra ve benzeri yazlar' FSEK m.85'de, 'resim ve portreler' ise FSEK m.86-87'de düzenlenmiştir. Anılan bu konuların ortak özelliği, eser niteliği taşımamalarına rağmen korunuyor olmalarıdır.

\section{BİR ESERIN ADI, ALÂMETLERİ VE ÇOĞALTILMIŞ NÜSHALARININ ŞEKILLERİ}

\section{A - Genel Olarak}

FSEK m.83'de 'Ad ve alâmetler' başlığı altında, 'bir eserin adı, alâmetleri ve çoğaltılmış nüshalarının şekillerinin', iltibasa meydan verebilecek tarzda, başka eserlerde ve çoğaltılmış nüshalarda kullanılamayacağı düzenlenmiştir. Bu düzenleme, "haksız rekabet yasağı ilkesine' dayanmaktadır. Ancak 'bir eserin adı, alâmetleri ve çoğaltılmış

\footnotetext{
* Ankara Üniversitesi Sosyal Bilimler Enstitüsü Özel Hukuk (Ticaret Hukuku) Ana Bilim Dalı Araştırma Görevlisi.
} 
nüshalarının şekilleri' üzerindeki hak, mali olmaktan çok, eser sahibinin kişilik haklarından doğan fer'i ve manevi bir hak niteliğindedir. O yüzden diğer manevi haklar gibi, bu hak da eseri takip eder. Dolayısıyla FSEK m.83'de korunan kişi eser sahibidir'.

\section{B - Koruma Konusu}

FSEK m.83'de 'bir eserin adı, alâmetleri ve çoğaltılmış nüshalarının şekilleri' korunmuştur.

\section{Eserin Adı}

Eserler, kamuya bir ad altında sunulur. Ad, eserin bir tür tamamlayıc1 parçasıdır $^{2}$. Eser üzerindeki bu ad, adeta sınai ürünleri birbirinden ayırt etmeğe yarayan markaların oynadığı rolü oynar ${ }^{3}$. Uygulamada her türlü esere bir ad konması yerleşmiş bir usûl olarak gözükmektedir. Eser sahibinin eserine verdiği ad, o eseri fikir ve sanat alanında, öbür fikir ve sanat ürünlerinden ayırır; özellikle edebiyat ve sinema alanında, eserin içeriğ i hakkında alıcıya fikir verir. Bu nedenle esere verilen ad, eserin sürümünde önemli bir etkendir. Aynı adın bir başka eserde kullanılması alıcıyı yanıltır ve eser sahibinin ekonomik çıkarlarına zarar verir. Dolayısıyla eserin adının korunmasında, eser sahibinin yanında alıcıların da yararı vardır. Haksız yararlanmaları engellemek amaciyla eser üzerindeki ad FSEK m.83 hükmü ile korünmuştur ${ }^{4}$.

\section{Eserin Alâmetleri}

FSEK m.83'de kullanılan bir eserin 'alâmetleri' ibaresiyle neyin kastedildiği madde metninden anlaşılamamaktadır. AYITTER, eserin alâmetleri (ve çoğaltılmış nüshaların şekilleri) kavramının 'eserin ayırıcı tanıtma vasıtaları' olduğunu belirtmekle yetinmiş, ayrıntıya girmemiştir'. TEKINALP ise, 'alâmet' sözcuiğüi ile neyin kastedildiğini açıklarken, öncelikle bu sözcügüun neyi kastetmediğini ifade etmiştir. Bu yazara göre, 'alâmet' sözcüğü ile 'eserin kapağı' ifade edilmemiştir. Çünkü, kapak, 'çoğaltılmış nüshaların şekilleri' kapsamındadır. Yine alâmet sözcügüunden, yayınevinin veya yapımcının markasını veya gene bir marka olan logosunu ya da yayıncının serileri birbirinden ayıran tasarımlarını anlamak olanağı da yoktur. TEKINALP, 'alâmet' sözcügüü ile, 'eseri simgeleyen bir resim veya

\footnotetext{
${ }^{1}$ HIRSCH, Ernst E.: Fikrî ve Sınaî Haklar, Ankara, 1948, s. 136; ARSLANLI, Halil: Fikri Hukuk Dersleri II, Fikir ve Sanat Eserleri, İstanbul, 1954, s. 53; EREL, Şafak N.: Türk Fikir ve Sanat Hukuku, 2. Bası, Ankara, 1998, s. 184-185.

${ }^{2}$ ARSLANLI, age, s. 53.

${ }^{3}$ ARSLANLI, age, s. 53; YARSUVAT, Duygun: Türk Hukukunda Eser Sahibi ve Hakları. İstanbul, 1977, s. 76.

${ }^{4}$ YARSUVAT, age, s. 76; AYITtER, Nuşin: Hukukta Fikir ve San'at Ürünleri, 2. Bası, Ankara, 1981, s. 83

${ }^{5}$ AYİTER, age, s. 84,
} 
ismin' kastedildiği görüşündedir ${ }^{6}$. Eseri simgeleyen resme, polis romanında yazarın bütün romanlarının karakteri olan komiserin veya köpeğin resmi; eseri simgeleyen isme ise, Reşat Nuri Güntekin'in 'Çalıkuşu' romanının karakterleri olan Feride-Kamuran isimleri örnek gösterilebilir.

\section{Eserin Çoğaltılmış Nüshalarının Şekilleri}

FSEK m.83'de kullanılan bir eserin 'çoğaltılmış nüshalarının şekilleri' ibaresiyle de neyin kastedildiği madde metninden açıkça anlaşılamamaktadır. Öğretide, 'çoğaltılmış nüshalarının şekilleri' kavramından 'eserin kapağının' kastedildiği ileri sürülmektedir ${ }^{7}$. Özellikle FSEK m.83/II'de kullanılan 'dış şekiller' ibaresi de, bu kavramı 'eserin kapağı' olarak anlamaya olanak vermektedir. Örneğin, (X) Yayınevi'nin, yayımladığı tüm kitaplarda, aynı kapak dizaynını kullandığını varsayalım. Bir anlamda bu kapak dizaynı, (X) Yayınevi'nin yayımladığı kitapları, diğer yayınevlerinin kitaplarından ayırmaya yaramaktadır. Dolayısıyla bu kapak dizaynı, tescil edilmiş olsun ya da olmasın, FSEK m.83 gereğince korunması gerekir.

\section{C - Koruma Koşulları}

FSEK m.83 incelendiğinde, bir eserin adı, alâmetleri ve çoğaltılmış nüshalarının şekillerinin korunması için üç koşulun varlığının gerektiği anlaşllmaktadır. FSEK m.83/V'de düzenlenen koruma hükümlerinden yararlanabilmek için bu koşulların 'birlikte' bulunması gerekir. Bu koşullar; söz konusu koruma konularının 'ayırt edici olması', 'iltibasa meydan verebilecek tarzda kullanılması' ve 'eserin kamuya sunulmuş olması'dır.

\section{Ayırt Edici Olma}

Bir eserin adı, alâmetleri ve çoğaltılmış nüshalarının şekillerinin FSEK m.83 kapsamında korunabilmesi için; herkes tarafından olağan olarak kullanılmaması ve ayırt edici niteliği bulunması gerekir. Bu koşul, FSEK m.83/II'de açıkça düzenlenmektedir. Bu fıkraya göre, 'birinci fıkra hükmü umumen kullanılan ve ayırt edici bir vasfı bulunmayan ad, alâmet ve dış şekiller hakkında uygulanmaz.'

Bir eser adı, alâmeti ve çoğaltılmış nüshalarını şekilleri, iki durumda 'ayırt edici olma koşulunu' sağlayabilir. Birinci durum 'orijinallik', ikinci durum ise 'tanınmışlık'tır. Bir başka deyişle, bir eser adı, alâmeti ya da çoğaltılmış nüshalarının şekilleri, ya 'orijinal (kendisine mahsus, değiş̧ik)' olduğu için, ya da 'tanınmış (şöhretli, bilinen)' olduğu için ayırt edicidir.

'Çalıkuşu', ‘İnce Memed', 'Yılanların Öcü' gibi eser adları, orijinal ve tanınmış nitelikte olduklarından ayırt edici olma koşulunu sağlarlar ve bu nedenle FSEK m.83 kapsamında korunurlar. Bununla birlikte bazı eser

\footnotetext{
${ }^{6}$ TEKINALP, Ünal: Fikn̂ Mülkiyet Hukuku, İstanbul, 1999, s. 272.
}

${ }^{7}$ TEKINALP, age, s. 272. 
adları, sadece eserin tipini ve cinsini belli eder. Bu tür adlar herkes tarafından kullanılabilir. 'Medeni Hukuk Dersleri', 'Türk Yemekleri' veya 'Modern Türk Şiiri' gibi eser adları bunlara örnek gösterilebilir. Bu tür eser adları, orijinal nitelikte olmadıklarından ayırt edicilik koşulunu sağlamazlar ve FSEK m.83 kapsammda korunmazlar ${ }^{8}$.

Bununla birlikte bir eserin ad, alâmet veya şekli ne kadar orijinal olursa olsun, eser niteliği taşımaz, dolayısıyla eserden ayrı ve kendi başına bir fikri hak konusu teşkil edemez ${ }^{9}$. Ancak, eser adlarının eser niteliği taşıdığına ilişkin özellikle $A B D$ ve İngiltere mahkemelerinde verilen kararlar da bulunmaktadır ${ }^{10}$.

Ayırt edicilik koşulunun gerçekleşmesi için bu iki durumun sadece birinin mi yoksa her ikisinin mi var olması gerektiği tartışmaya açıktır. YARSUVAT, daha yeni tarihli bir eser kendisinden önce yazılmış ve fakat tanınmamış bir eserin adını taşıyorsa ve yeni tarihli eser eski tarihliden daha büyük bir üne sahip olabilmiş ise artık haksız rekabetten söz etmenin olanaklı olmadığı görüşündedir. YARSUVAT, burada eski tarihli eserin yarattığ 1 şöhretten (tanınmışlıktan) yararlanılmadığı gerekçesiyle bu sonuca ulaşmaktadır ${ }^{\prime \prime}$. Dolayısıyla YARSUVAT, ayırt edici olma koşulunu 'tanınmışlık' durumuna indirgemekte, tanınmamış ama orijinal eser adlarını FSEK m.83'deki koruma alanı dışına çıkarmaktadır. Kanaatimce, ayırt edicilik koşulunun gerçekleşmesi için, orijinallik ve tanınmışlık durumlarından sadece birinin var olması yeterlidir. Sadece tanınmıß̧ eser adlarını koruma hükümlerine tabi kılmak, kanun koyucunun amacını daraltmak anlamına gelir.

\section{2. İltibasa Meydan Verebilecek Tarzda Kullanılma}

FSEK m.83'deki koruma hükümlerinin uygulanabilmesinin ikinci koşulu, eserin ad, alâmet ve çoğaltılmış nüshalarının şekillerinin iltibasa meydan verebilecek tarzda, başka eserlerde veya çoğaltılmış nüshalarında kullanılmasıdır. İltibas sözlükte, 'iki şeyin birbirine, biri sanki öteki sanılacak kadar benzemesi', kısaca 'yanıltıcı karışılık' olarak tanımlanmıștır ${ }^{12}$. İltibas, TTK $\mathrm{m} .57 / 5^{\prime}$ de, haksız rekabete neden olan iyiniyet

\footnotetext{
${ }^{8}$ YARSUVAT, age, s. 77-78; AYITER, age, s. 84; EREL, age, s. 185.

${ }^{9}$ HIRSCH, Fikri Haklar, s. 136; ARSLANLI, age, s. 53; EREL, age, s. $184-185$.

Buna karşılık AYITER, nadir bazı hallerde eserin adının kendi başına özellik taşıyan bir yaratma olabileceğini, Alman mahkeme içtihatlarında bazı hallerde eser adlarının eser niteliği taşıdığının kabul edildiğini, ayrıca Fransa Fikir Hakları Yasası'nın 5. maddesinde, bir düşünce ürününün adının, niteliği bakımından özgün olduğu takdirde, eser ile aynı korumadan yararlanacă̆ının düzenlendiğini belirtmektedir. Bkz. AYİTER, age, s. 84.

10 Bu konuda ayrıntılı olarak bkz: BEŞIROĞLU, Akın: Düşünce Ürünleri Üzcrindeki Haklar, Fikir Hukuku, Birinci Cilt, Temel Kurallar, 2. Bası, Ankara, 2002, s. 100-104

"YARSUVAT, age, s. 77.

'2 YlLMAZ, Ejder: Hukuk Sözlüğü, 4. Baskı, Ankara, 1992, s. 404.
} 
kurallarına aykırı hareketler içinde düzenlenmiştir. FSEK, iltibas ile ilgili olarak haksız rekabet hükümlerine atıf yaptığına göre, iltibasın olup olmadığ ${ }_{1}$ haksız rekabet ilkelerine göre belirlenecektir ${ }^{13}$.

FSEK m.83/I'de, 'iltibasa meydan verebilecek surette' ifadesinin kullanılması dikkat çekicidir. Bu ifadeden anlaşılacağı gibi, kanun koyucu, FSEK m.83 hükmünün uygulanabilmesi için, eserin adı, alâmetleri ve çoğaltılmış nüshalarının 'iltibasa yol açmasını' zorunlu görmemekte, 'iltibasa meydan verebilecek tarzda kullanılmasını' yeterli görmektedir. Böylece, maddenin uygulama alanı genişletilmiş olmaktadır ${ }^{14}$. Dolayısıyla iltibasa meydan vermek; ad, alâmet veya şekillerin sadece asıl eserde olduğu gibi kullanılmasını değil, herhangi bir şekilde karıştırmaya yol açabilecek tarzda kullanılmasinı da ifade eder ${ }^{15}$.

FSEK m.83/I'in, sadece ad benzerliği gibi dar bir alanda kalınmayıp, adın göz ve kulakta yapabileceği etkiler de hesaba katılarak geniş bir biçimde yorumlanması gerekir. Sözgelimi, başka bir kitaba çağrışım yapan bir ad koyarak bir kitabın piyasaya sürülmesi halinde iltibasa meydan verilmiş olur ${ }^{16}$. Örneğin, (X) isimli bir yazarın, 'Insanları Aldatmak' adında, içeriği Ahmet Altan'ın 'Aldatmak' romanından tamamen farklı bir roman yazdığını, ama kitabın kapağında 'INNSANLARI' sözcüğünün küçük puntolarla, 'ALDATMAK' sözcüğünün ise büyük puntolarla dizayn edildiğini varsayalım. Bu olayda, iltibasa meydan verebilecek tarzda eser adı kullanıldığg için, FSEK m.83 hükmünün uygulanabilmesi gerekir.

Kanun koyucunun 'iltibasa meydan verebilecek tarzda kullanılması' koşulunu aramasının önemli bir sonucu da, eserin adı, alâmeti ve çoğaltılmış nüshalarının şekillerinin bir başka eserde kullanılabilmesidir. Bir başka deyişle, iltibasa meydan vermemesi koşuluyla, bir eserde kullanılan ad, alâmet ve dışs şekiller, başka bir eserde kullanılabilir. Dolayısıyla, eser

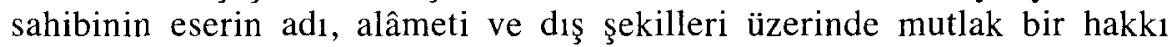
yoktur ${ }^{17}$.

Haksız rekabetin gerçekleşmesi için eser adının mutlaka aynı cins eserde kullanılması da gerekmez. İltibasa meydan verme tehlikesi, özellikle roman adlarının filmlerde kullanılması durumunda da söz konusu olabilir ${ }^{18}$.

\footnotetext{
${ }^{13}$ TEKİNALP, age, s. 118.

${ }^{14}$ AYÍTER, age, s. 84.

${ }^{15}$ EREL, age, s. 185-186.

${ }^{16}$ YARSUVAT, age, s. 77.

${ }^{17}$ Fuat Hulusi DEMIRELLİ tarafından hazırlanan yasa taslağının 13. maddesinin 2. cümlesi 'Eser. bir ad altında yayınlanmışsa, bu adı, hiç kimse başka bir esere veremez.' şeklindeydi. Bu hüküm HIRSCH tarafından, eserin adı üzerinde eser sahibine çok geniş bir imtiyaz (ayrıcalık) hakkı tanıdığı için eleştirilmiştir. Bkz: HIRSCH, Ernst E.: Hukuki Bakımdan Fikrî Sây, İkinci Cilt, Fikri Haklar (Telif Hukuku), İstanbul, 1943, s. 21-22.

${ }^{18}$ A YİTER, age, s. 85.
} 


\section{Kamuya Sunulmuş Olma}

Bir eserin ad, alâmet ve çoğaltılmış nüshalarının şekillerinin korunması için, başka eserlerde veya çoğaltılmış nüshalarında iltibasa meydan verebilecek tarzda kullanılması yeterli değildir. Korumanın dayanağı haksız rekabet yasağı ilkesi olduğundan, eserin bu ad altında kamuya sunulması, alâmet ve şekli taşıyan nüshalarının tedavüle konması da gereklidir. Kamuya sunulmuş olma koşulunun sonucu olarak, uyuşmazlık konusu iki eserden, önce kamuya sunulan eser, koruma hükümlerinden yararlanacaktır ${ }^{19}$.

\section{D - Koruma Hükümleri}

Bir eserin adı, alâmetleri ve çoğaltılmış nüshalarının şekilleri, başka eserlerde ve çoğaltılmış nüshalarda iltibasa meydan verebilecek tarzda kullanılmışsa, haksız rekabete ilişkin hükümleri uygulanır (FSEK m.83/V).

Haksız rekabet, Borçlar Kanunu'nun 48. maddesinde ve Türk Ticaret Kanunu'nun 56-65. maddeleri arasında düzenlenmiştir. TTK m. 58-63'de haksız rekabette bulunan kişinin hukuki sorumluluğu, TTK $\mathrm{m} .64-65$ 'de ise haksız rekabette bulunan kişinin cezai sorumluluğu düzenlenmiştir. TTK m.58'de haksız rekabet nedeniyle açılabilecek hukuk davaları; 'tesbit', 'men (durdurma)', 'haksiz rekabetin sonucu olan maddi durumun ortadan kaldırılması', 'maddi ve manevi tazminat davası' olarak sayılmıştır. Haksız rekabet dolayısıyla tesbit, men ve hukuka aykırı durumun ortadan kaldırılması davalarının açılabilmesi için failin kusurlu olması şart değildir. Buna karşılık tazminat davalarının açılabilmesi için failin kusurunun bulunması gerekir. Söz konusu davalar, 'zarar gören veya zarar görme tehlikesine maruz bulunan kimseler', 'müssteriler' ve 'mesleki ve ekonomik birlikler' tarafından açılabilir (TTK m.58/I-II-III). Örneğin, kitabın yazarı, yayınevi, yapımcı veya iltibasa uğrayarak yanlış kitabı satın alan okuyucu bu davaları açabilir. Davalı ise, haksız rekabet teşkil eden davranışta bulunan kişidir. Haksız rekabet davalarının, davaya hakkı olan tarafın bu hakkının doğumunu öğrendiği günden itibaren 1 yil ve her halde bunların doğumundan itibaren 3 yıl içinde açılması gerekir (TTK m. 62) ${ }^{20}$. Türk Ticaret Kanunu'nun haksız rekabete ilişkin bu hükümlerinin uygulanabilmesi için, haksız rekabette bulunan kişinin, diğer deyişle mütecavizin tacir olması da gerekli değildir (FSEK m.83/V).

Bununla birlikte, bir eserin adı, alâmetleri ve çoğaltılmış nüshalarının şekilleri sadece haksız rekabet hükümleriyle değil, aynı zamanda, şartların varlığı halinde, marka ve tasarım hukukuna göre de korunabilir ${ }^{21}$. Ayrıca kanun koyucu, bir eserin adı, alâmetleri ve çoğaltılmış nüshalarının

\footnotetext{
${ }^{19}$ ARSLANLI, ge, s. 53; YARSUVAT, age, s. 76; AYITER, age, s. 84-85; EREL, age, s. 185 .

${ }^{20}$ Haksız rekabet hükümlerine ilişkin ayrıntılı olarak bkz: ARKAN, Sabih: Ticarî İşletme Hukuku, 6. Baskı, Ankara, 2001, s. 302-309.

${ }^{21}$ TEKINALP, age, s. 118, 272.
} 
şekillerinin korunmasını; eser niteliğinin veya eser sahipliğinin tespitinde aranan koşulların gerçekleşmesine bağlı tutmamıştır (FSEK m. 83/III).

\section{E - Koruma Süresi}

Bir eserin adı, alâmetleri ve çoğaltılmış nüshalarının şekilleri üzerindeki haksız rekabet çerçevesindeki korumanın süresi ile ilgili bir hüküm FSEK'nda yer almamaktadır. Öğretide egemen görüşe göre, haksız rekabet yasağına dayanan bu koruma, haksız rekabet imkanı ve iltibas tehlikesi bulunduğu sürece var olmalıdır. Korumanın kalkması için eserin ticari değerinin kalmamış olması, iltibasa yol açma imkanının sona ermesi gerekir. Bunun için eserin tedavülden kalkmış, tükenmiş olması yahut eser için geçerli olan koruma sürelerinin dolması da gerekli değildir. Diğer deyişle, FSEK m.83 hükmü, koruma süresi sona eren eserlere de uygulanır. Eserin fikir ve sanat alanında halen önem taşıyor olması; ad, alâmet veya şeklinin korunması için yeterlidir ${ }^{22}$. Öğretide, herhangi bir sımırlama koymaksızın 'sonsuza dek' korumanın devam edeceği de ileri sürülmektedir ${ }^{23}$.

FSEK m.83/IV, Basın Kanunu'nun 14. maddesindeki mevkute adları hakkındaki hükmü saklı tutmuştur. 5680 sayılı Basın Kanunu'nun 14. maddesinde, mevkute (belli zamanlarda çıkan yayın organı) çıkarılacağına ilişkin beyannamenin o yerin en büyük mülki amirine verildiği tarihten itibaren 1 yıl içinde mevkute yayımlanmazsa veya yayımlanmaya başlandıktan sonra yayımına 5 yıl süreyle ara verilirse, beyannamenin hükümsüz kalacağı ve sağladığı hakların (bu arada mevkutenin adı üzerindeki hakkın) düşeceği düzenlenmiştir.

\section{III. İ̧̧ARET, RESIM VEYA SES NAKLINE YARAYAN ARAÇLAR}

\section{A - Genel Olarak}

FSEK m. 84 'de 'İ̧aret, resim ve ses' başlığı altında, 'bir işareti, resmi veya sesi, bunları nakle yarayan bir alet üzerine tesbit eden veya ticari maksatlarla haklı olarak çoğaltan yahut yayan kimsenin, aynı işaretin, resmin veya sesin üçüncü bir kişi tarafından aynı vasıtadan faydalanılmak suretiyle çoğaltmasını veya yayımlamasını men edebileceği' düzenlenmiştir. Bu düzenleme de, FSEK m.83'de olduğu gibi, 'haksız rekabet yasağı ilkesine' dayanmaktadır. FSEK m.84'de korunan kişi 'bir işareti, resmi veya sesi nakle yarayan araç üzerinde tesbit eden' kimse, diğer bir deyişle yapımcılardır ${ }^{24}$. Korumanın amacı, yapımcıların emeğinden başkalarının yararlanmalarını engellemektir. Zira, bu türlü araçların yapımı, sermaye ve örgüt gerektiren, ekonomik yönü ağır basan bir faaliyettir. Teknolojinin

\footnotetext{
${ }^{22}$ HIRSCH, Fikrî Sây, s. 22; ARSLANLI, age, s. 54; AYİTER, age, s. 85; EREL, age, s. 186; TEKINALP, age, s. 272.

${ }^{23}$ YARSUVAT, age, s. 78 .

${ }^{24}$ Yapımcı kavramına ilişkin olarak bkz: EREL, age, s. 174-175.
} 
gelişmesi ile birlikte, bu tür araçların fazla zahmet gerektirmeden çoğaltılmaları olanaklıdır. Bu durumda, bu tür araçları imal eden kişilerin menfaatleri ihlal edilmiş olacaktı́r ${ }^{25}$.

\section{B - Koruma Konusu}

FSEK m.84'de düzenlenen koruma konusu, eser niteliğinde olmayan 'işaret, resim veya ses nakline yarayan araçlardır'. FSEK m.84'de geçen 'nakil' sözcü̆ğỉ, öğretide haklı olarak eleştirilmiştir. Madde metninde 'nakil' sözcüğünden dolayı, 'işaret, resim veya sesin bir yerden başka bir yere iletilmesini için kullanılan araçların (sözgelimi ulaşım araçlarının)' korunduğu sanılmaktadır. Oysa madde metninde, 'işaret, resim veya sesin tekrarma yarayan araçlar' ifade edilmek istenmektedir ${ }^{26}$. Tekrara yarayan araçlara örnek olarak; gramofon plakları, teyp bantları, video teypler, fotoğraf negatifleri, ofset baskı filmleri, teksire yarayan klişeler gösterilebilir. Dolayısıyla 'nakle yarayan araçlar' ifadesini 'tekrara yarayan araçlar' biçiminde anlamak gerekir' ${ }^{27}$.

Ayrıca eser niteliği taşımayan 'her nevi fotoğraflar' (mesela, bir filozofun ya da siyaset adamının yaşadığı veya doğduğu evin fotoğrafları), 'benzer yöntemlerle kayda alınan resimler' ve 'sinema ürünleri' (mesela, bir romancının videoya kaydedilmiş Nobel Armağanı töreni gibi) de FSEK m.84'e göre korunurlar.

\section{C - Koruma Koşulları}

İşaret, resim veya sesi nakle yarayan araçların korunabilmesi ve dolayısıyla FSEK m.84/II'deki koruma hükümlerinin uygulanabilmesi için şu koşulların 'birlikte' gerçekleşmiş olması gerekir:

1. İşaret, resim veya sesi nakle yarayan araçların, 'FSEK'nun esere veya komşu haklara ilişkin hükümlerinin, Markaların Korunması Hakkındaki KHK'nin ve Endüstriyel Tasarımların Korunması Hakkındaki KHK'nin kapsamına girmemesi' gerekir. Örne ğin, (X) isimli ünlü bir ses sanatçısının piyasaya çıkardığı bir CD'nin izinsiz olarak çoğaltılması durumunda FSEK m.84 uygulanmaz. Çünkü bu CD 'eser' kapsamında yer aldığından, eserin korunmasına ilişkin hükümler uygulanacaktır. Bir işaret, marka ise ya da bir ses veya resim, fikir ve sanat eseri niteliği taşıyorsa, bunlar kayda alındıkları takdirde ya 'eser' veya 'komşu haklar' çerçevesinde ya da 'tasarım' yahut 'marka' olarak korunurlar. Ancak, bir işaret, resim veya ses bu düzenlemelerden hiçbirinin kapsamma girmiyorsa, bunlanı nakle yarayan araçlar, FSEK m.84'e göre

\footnotetext{
${ }^{25}$ ARSLANLI, age, s. 55; AYITTER, age, s. 81.

${ }^{26}$ AYÍTER, age, s. 81

27 'Nakle yarayan aletler' ifadesi FSEK m.44'de de geçmekte idi. Bu madde de, 1995 yılında 4110 sayılı Kanun'un 18. maddesi ile değişiklikler yapılmış, 'nakle yarayan aletler' ifadesi de, 'tekrara yarayan aletler' biçiminde düzeltilmiştir.
} 
(dolayısıyla Borçlar Kanunu'nun ve Türk Ticaret Kanunu'nun haksız rekabet hükümlerine göre) korunurlar ${ }^{28}$.

2. İşaret, resim veya sesi nakle yarayan araçları, ticari maksatlarla çoğaltan veya yayan kimsenin 'haklı olması' gerekir ${ }^{29}$. Haklı olma koşulu FSEK m.84/I'de açıkça düzenlenmiştir. Haklı olma, işaret, resim veya sesi nakle yarayan araçları çoğaltmaya ve yaymaya yetkili olma anlamındadı ${ }^{30}$. Sözgelimi, (X) isimli kişinin resmini çoğaltan veya yayan kimsenin, öncelikle, (X)'den FSEK m.86 gereğince muvafakat alması gerekir. Muvafakat alınmadan yapılmış olan çoğaltma ve yayma 'haklı olmayacağından', çoğaltan ve yayan kimse FSEK m.84 kapsamında korunmayacaktır.

3. İşaret, resim veya sesin yapımcı tarafından nakle yarayan bir araç üzerinde 'tesbit edilmesi, çoğaltılması ve yayımlanması' gerekir. 'Tespit', işaret, resim ve seslerin bir araç üzerine herhangi bir yöntemle algılanabilmesini, çoğaltılabilmesini ya da başka bir yoldan kamuya iletilmesini sağlayacak şekilde kaydedilmesidir ${ }^{31}$. 'Çoğaltma', aslın aynısının kopyalanmasıdır' ${ }^{32}$. 'Yayma' ise, çoğaltılmış aracın, dağıtılma, satış, kiralanma, ödünç verme veya herhangi bir yolla ticarete sunulması demektir. Yayma, kısaca ticaret mevkiine koyma (piyasaya sürme) anlamına da gelir ${ }^{33}$. Tesbit, çoğaltma ve yayma birbirini izleyen aşamalar görünümündedir. Bu noktada, FSEK m.84'ün uygulanabilmesi için, yapımcı tarafından işaret, resim veya sesin, nakle yarayan araçlar üzerinde tesbit edilmesinin mi yeterli olacağı, yoksa tesbit edildikten sonra çoğaltılmasının mı gerekeceği, hatta çoğaltıldıktan sonra da yayımlanmasının mı aranacağı tartışmaya açıktır. FSEK m.84 metninde, tesbit, çoğaltma ve yayma sözcükleri arasında 'veya' bağlacı kullanıldığına göre, tesbit edilen ama çoğaltılmayan, çoğaltılan ama yayımlanmayan araçların da koruma kapsamında olduğu ileri sürülebilir. Ancak, FSEK m.84'deki korumanın dayanağı haksız rekabet yasağı ilkesi olduğundan, bu hükümlerin uygulanabilmesi için araçların 'çoğaltılarak tedavüle konması (yayımlanması)' gerekir ${ }^{34}$. Bu nedenle FSEK m.84 metnindeki 'veya' bağlacını 've' olarak anlamak yerinde olur.

4. İşaret, resim veya sesi nakle yarayan araçların, üçüncü kişi tarafından 'çoğaltılması ve yayımlanması' gerekir. Üçüncü koşulda karşılaşılan sorunun aynısı bu durumda da söz konusudur. İşaret, resim veya sesi nakle yarayan araçların FSEK m.84 kapsamında korunabilmesi için, üçüncü kişi tarafından sadece çoğaltılmasının mı yeterli olacağı, yoksa

\footnotetext{
${ }^{28}$ TEKINALP, age, s. 272-273.

${ }^{29}$ TEKINALP, age, s. 273.

${ }^{\text {*) }}$ BELGESAY, M. Reşit: Fikir ve Sanat Eserleri Kanunu Şerhi, İ stanbul, 1955, s. 143.

${ }^{31}$ TEKINALP, age, s. 264.

32 TEKINALP, age, s. 175.

${ }^{33}$ TEKINALP, age, s. 176-177.

${ }^{34}$ AYÍTER, age, s. 83.
} 
çoğaltmayla birlikte yayımlanmasının mı gerekeceği tartışmaya açıktır. Üçüncü koşulda benimsenen çözüme paralel olarak, bu durumda da, koruma hükümlerinin uygulanabilmesi için araçların 'çoğaltılması ve yayımlanması' gerekece $\breve{g}$ kabul edilmelidir ${ }^{35}$.

5. Korumanın söz konusu olabilmesi için, uiçüncü kişi tarafından yapılan çoğaltma ve yayma fiillerinin, 'söz konusu araçlardan faydalanılmak suretiyle' yapılmış olması gerekir. Dolayısıyla, söz konusu araçlardan yararlanmamak kaydıyla, işaret, resim veya sesler üçüncü kişiler tarafından serbestçe tespit edilip çoğaltılabilir ${ }^{36}$.

\section{D - Koruma Hükümleri}

Nakle yarayan bir araç üzerinde tespit edilen 'işaret, resim veya sesin', üçüncü bir kişi tarafından aynı vasıtadan faydalanılmak suretiyle çoğaltması veya yayımlanması durumunda, haksız rekabete ilişkin hükümleri uygulanır (FSEK m.84/II). Haksız rekabet, Borçlar Kanunu'nun 48. maddesinde ve Türk Ticaret Kanunu'nun 56-65. maddeleri arasında düzenlenmiştir ${ }^{37}$. Türk Ticaret Kanunu'nun haksız rekabete ilişkin hükümlerinin uygulanabilmesi için, haksız rekabette bulunan kişinin tacir olması da gerekli değildir (FSEK $\mathrm{m} .84 / \mathrm{II}$ ). Örneğin, bir gazeteci, sinema sanatçısı (X) ile yaptığı bir ropörtajı banda almış ve bandları piyasaya sürmüşse, bu bandları çoğaltıp yayan üçüncü kişileri, bu üçüncü kişiler tacir olmasalar bile, TTK'nun haksız rekabet hükümlerine göre dava edebilir.

\section{E - Koruma Süresi}

İşaret, resim veya ses nakline yarayan araçlar üzerindeki korumanın süresi ile ilgili bir hüküm FSEK'nda yer almamaktadır. Bu konu, Alman FSEK'nda düzenlenmiş ve koruma süresi 25 yıl olarak tespit edilmiştir. Öğretide, eserlerin korunmasına ilişkin sürelerin, işaret, resim veya ses nakline yarayan araçların korunmasında kıyasen uygulanabileceği, ancak eser korumasından daha kısa sürelerin kabul edilmesinin uygun olacağı ileri sürülmektedir ${ }^{38}$.

\footnotetext{
${ }^{35}$ FSEK'nun hazırlanmasında etkin görev alan HIRSCH, 'Fikrî Sây' kitabında 'mihaniki aletin yalnı çoğaltılması değil, aynı zaman da yayımı da hak sahibi tarafından men edilebilir' demektedir. Bu ifadeden HIRSCH'in, işaret, resim veya sesi nakle yarayan araçların FSEK m.84 kapsamında korunabilmesi için, üçüncü kişi tarafından sadece çoğaltılmasının yeterli olacağı, çoğaltmayla birlikte yayımlanmasının zorunlu olmadığı görüşünde olduğu sonucu çıkmaktadır. Bkz: HIRSCH, Fikrî Sây, s. 24.

${ }^{36}$ AYITER, age, s. 82

${ }^{37}$ Haksız rekabete ilişkin hükümler için bkz. yuk. II - D.

${ }^{38}$ ARSLANLI, age, s. 56; AYITTER, age, s. 53.
} 


\section{MEKTUP, HATIRA VE BENZERI YAZILAR \\ A - Genel Olarak}

FSEK m.85'de 'Mektuplar' başlığı altında, 'eser mahiyetinde olmasalar bile, mektup, hatıra ve benzeri yazıların, yazanların ve bunlar ölmüşse 19/I'de saylanların muvafakati olmadan, yazanın (ve muhatabin) ölümünden 10 yıl geçmedikçe yayımlanamayacağı' düzenlenmiştir. Bu düzenleme, 'kişiliğin korunması ilkesine' dayanmaktadır. Çünkü, mektup, hatıra ve benzeri yazılar herkesin özel hayatının ve kişiliğinin parçasını oluşturur. Her kişi çeşitli kimselere yazdığı mektuplarda, tuttuğu günlüklerde veya anı defterinde kişisel hayatı hakkında bilgilere, ilişkilerine, başkaları hakkında görüşlerine, çeşitli konulardaki düşüncelerine yer verir ve bunların özel hayat dünyasından kendi iradesi olmadan çıkmasını istemez. Mektupların muhataplan içinde durum aynıdır ${ }^{39}$. Dolayısıyla FSEK m.85' de korunan kişi mektup, hatıra ve benzeri yazıları yazanlar ve bu yazılara muhatap olanlar; korunan hak ise yazanın ve muhatabın kişilik hakkıdır.

\section{B - Koruma Konusu}

FSEK m.85'de 'mektup, hatıra ve benzeri yazılar' korunmuştur. Kanun koyucunun 'buna benzer yazılar' ifadesinden dolayı, madde metnini geniş yorumlamak olanaklıdır. Öğretide, FSEK m.85 kapsamına 'tespit edilmiş olan sözlerin' ve 'günlüklerin' de gireceği ileri sürülmektedir" ${ }^{4()}$ 'Elektronik postaların', 'tebrik kartlarının' da madde kapsamına girebileceği söylenebilir. FSEK m.85/I kapsamında korunan mektup, hatıra ve benzeri yazılar edebi eser niteliğinde olabilecekleri gibi, böyle bir özellik taşımayan alelâde yazılar da olabilir. Bu bakımdan edebiyatçı kimliğine sahip bir kimsenin her yazdığının edebi eser olması gerekmediği gibi, bunun tersi de doğrudur.

\section{C - Koruma Koşulları}

Mektup, hatıra ve benzeri yazılara ilişkin FSEK m.85/III-IV'de düzenlenen koruma hükümlerinin uygulanabilmesi için, 'bunların yayımlanmasına muvafakat verilmemiş olması' ve 'muvafakat verme süresinin geçmemiş olması' koşullarının birlikte bulunması gerekir.

\section{Muvafakat Verilmemiş Olması}

FSEK m.85/I-II'e göre, mektup, hatıra ve buna benzer yazıların yayımlanabilmesi ${ }^{41}$ için yetkili kişilerin muvafakati gerekmektedir. Maddede

\footnotetext{
${ }^{39}$ TEKINALP, age, s. 273.

4) AYİTER, age, s. 87-88; EREL, age, s. 189; TEKİNALP, age, s. 273.

${ }^{41}$ FSEK m.86/I'de 'yayın', FSEK m.86/II'de 'yayım' ifadesinin kullanıldığı görülmektedir. 'Yayın' neşir, neşriyat anlamında isim; 'yayım' ise yayma, neşretme anlamında bir fiildir. FSEK m.86/I'de yayma fiili kastedildiğine göre, kanun koyucunun 'yayım' sözcüğü yerine ‘yayın' sözcüğünü kullanması hatahıdır.
} 
geçen 'yayım' tabirine rağmen, buradaki yasağın sadece FSEK m.7 ve m.23 anlamındaki yayımı değil, kamuya sunmanın yahut alenîleştirmenin diğger türlerini de kapsadığı öğretide ileri sürülmektedir. Örneğin, böyle bir mektup, hatıra veya benzeri yazılara dayanan bir sinema eseri yaratılamaz yahut bir konferans verilemez ${ }^{42}$. Muvafakat vermeye yetkili kişilerin, FSEK m.85/III'de düzenlenen koruma hükümlerinden yararlanabilmeleri için, muvafakatin verilmemiş olması gerekir.

Tek taraflı bir hukuki işlem olan muvafakat, ivazlı veya ivazsız; yazılı veya sözlü; açık (sarih) veya örtülü (zımnî) verilebilir ${ }^{43}$. Öğretide, mektup, hatıra ve benzeri yazıların yayımlanmasi maddi bir menfaat temin edecek nitelikte olduğunda, FSEK m.52 gereğince, muvafakatin yazılı şekilde verilmesi gerektiği de ileri sürülmektedir ${ }^{44}$.

Muvafakat vermeye yetkili kişi; mektup, hatıra ve buna benzer yazıları yazan kişidir. Bu kişi hayatta değilse, FSEK m.19/I'de yazılı kişilerin muvafakati aranır. FSEK m.19/I'de yazılan kişiler sırasıyla; 'vasiyeti tenfiz memuru', vasiyeti tenfiz memuru tayin edilmemişse 'mektup, hatıra ve benzeri yazıları yazanın sağ kalan eşi ile çocukları ve mansup mirasçıları', 'ana babası' ve 'kardeşleri'dir. FSEK m.19/I metninden yetkili kişilerin dört grupta toplandığı görülmektedir. Birinci grupta vasiyeti tenfiz memuru; ikinci grupta; yazarın (mirasçının) sağ kalan eşi, çocukları ve mansup mirasçıları, üçüncü grupta; yazarın ana-babası, dördüncü grupta da yazarın kardeşleri bulunmaktadır. Birinci grupta vasiyeti tenfiz memuru varken, ikinci, üçüncü ve dördüncü gruptaki mirasçılar; ikinci grupta mirasçı varken, üçüncü ve dördüncü gruptaki mirasçılar muvafakat vermeye yetkili değildir $^{45}$. Görüldüğü gibi, bir grupta birden çok yetkili kişi bulunabilir. Bu durumda muvafakat, ögretideki bir görüşe göre ittifakla (oybirliği halinde) verilmelidir. Eğer kişiler ittifakla karar alamazlarsa, yargıcın müdahalesi gerekir $^{46}$. Öğretide, yayımı yazarı veya muhatabı tarafından açıkça yasaklanmış bulunan mektup, hatıra ve benzeri yazıların, onların ölümünden sonra FSEK m.19/I'de yazılan yetkili kişilerce bile yayımına muvafakat verilemeyeceği de ileri sürülmektedir ${ }^{47}$.

Eser niteliğ taşımayan mektup, hatıra ve benzeri yazıların, yazanın ölümünden sonra yayımlanabilmesi için FSEK m.19/I'de yazılan kişilerin muvafakatinin aranması, eser niteliğinde olmayan bu tür belgelerin yayımlanabilmesi için, eser üzerindeki manevi hakların intikalini düzenleyen

\footnotetext{
42 ARSLANLI, age. s. 57; YARSUVAT, age, s. 70; AYITER, age, s. 86; EREL, age, s. 187.

${ }^{43}$ Muvafakatin hukuki niteliğine ilişkin daha geniş bilg̨i için bkz. aşa. V - C - 1

${ }^{44}$ BELGESAY, age, s. 145-146.

${ }^{45}$ BELGESAY, age, s. 59.

${ }^{40}$ BELGESAY, age, $s .59$

${ }^{47}$ EREL, age, s. 188.
} 
FSEK m.19/I'in uygulanmaması gerekeceği nedeniyle öğretide eleştirilmektedir ${ }^{48}$.

Kanun koyucu 'mektuplar' bakımından sadece mektupları yazanın veya yazan kişi hayatta değilse, FSEK m.19/I'de yazılı kimselerin muvafakatini yeterli görmemiştir. Bu kişilerle birlikte, mektubun yazıldı ğı muhatabın veya muhatap hayatta değilse, FSEK m.19/I'de yazılı kimselerin de muvafakatini aramıştır. Gönderilmiş mektuplarda muhatabın veya diğer yetkili kişilerin muvafakatinin gerekeceği madde metninden açıkça anlaşılmaktadır. Ancak, yazıldığı halde muhataba gönderilmemiş mektuplar için de, muhatabın veya diğer yetkili kişilerin muvafakatinin aranıp aranmayacağı tartışmaya açıktır. Öğretide, muhatabın veya mirasçıların elinde olmayan mektupların yayımlanması için de, FSEK m.85/II'deki muvafakat verme koşulunun gerektiği ileri sürülmektedir ${ }^{49}$.

Kanun koyucunun sadece mektuplar için aradığı bu ek muvafakat yetkisini, mektup gibi muhatap gerektiren diğer yazılara da teşmil etmek olanaklıdır. Bu nedenle, bir muhataba yazılan 'elektronik postaların' ve 'tebrik kartlarının' yayımlanması için de, bu yazıların muhataplarının muvafakatleri gerekecektir. Bununla birlikte 'hatıra ve benzeri yazılarda ad1 geçen kişileri' muhatap saymak ve hatıra ve benzeri yazıların yayımında bu kişilerin muvafakatlerini aramak, FSEK m.85/I-II hükümleri çerçevesinde olanaklı gözükmemektedir. Elbette, hatıra ve benzeri yazılarda adı geçen kişiler, yayımlanan bu yazıların içeriğinde kendilerinin kişilik haklarına saldırıda bulunulduğunu düşünürlerse, genel hükümlere göre yazar ve yayımcı aleyhine dava açabilirler. Ancak, 'hatıra ve benzeri yazılarda adı geçen kişilerin' söz konusu yazıların yayımlanmasına muvafakat verme yetkileri yoktur.

\section{Muvafakat Verme Süresinin Geçmemiş Olması}

FSEK m.85/III'de düzenlenen koruma hükümlerinden yararlanabilmeleri için, muvafakat verme süresinin geçmemiş olması gerekir.

a) 'Mektuplar' açısından muvafakat verme süresi, hem mektubu yazan, hem de muhatap hayatta olduğu sürece işlemez. İkisinden herhangi birinin ölmesi durumunda da muvafakat verme süresi işlemez. Her ikisinin de ölmesi durumunda, ikinci ölümden itibaren 10 yil içinde her iki tarafın yetkili kişileri ittifakla muvafakat vererek mektupları yayımlatabilirler. Yazarın ve muhatabın ölümünden sonra 10 yıl geçtikten sonra, mektuplar serbest hale gelir. Örneğin, 1.1.1971 tarihinde (A)'nın (B)'ye bir mektup yazdığını, (A)'nın 1.1.1985 tarihinde, (B)'nin de 1.1.2003 tarihinde öldüğünü varsaydığımızda, söz konusu mektup ancak 1.1.2013 tarihinde

\footnotetext{
AYITER, age, s. 87; EREL, age, s. 188-189.

${ }^{49}$ EREL, age, s. 188.
} 
serbest kalacak ve muvafakate gerek kalmadan yayımlanabilecektir. Söz konusu örneğimizde, 1.1.1971 ile 1.1.1985 tarihleri arasında (A) ve (B); 1.1.1985 ile 1.1.2003 tarihleri arasında (A)'nın mirasçıları ile (B); 1.1.2003 ile 1.1.2013 tarihleri arasında (A)'nın mirasçları ile (B)'nin mirasçıları muvafakat vermeye yetkilidir. Dikkat çekici olan nokta, (A) 1.1.1985 tarihinde ölmesine rağmen, (A)'nın mirasçıları 1.1.2013 yılına kadar muvafakat vermeye yetkili olacaklardır. Dolayısıyla, mektuplar açısından, yazar veya muhataptan birinin ölmesi durumunda, ölenin mirasçılarının muvafakat verme yetkilerinin süresini 10 yılla sınırlı düşünmemek gerekir.

b) 'Hatıra ve benzeri yazılar' açısından muvafakat verme süresi, bunları yazan kişi hayatta olduğu sürece işlemez. Yazar ölmüşse, muvafakat vermeye yetkili kişiler, yazarın ölümünden itibaren 10 yıl içinde yazıların yayımlanmasına muvafakat verebilirler. Yazarın ölümünden 10 yıl geçtikten sonra, hatıra ve benzeri yazilar serbest hale gelir.

\section{D - Koruma Hükümleri}

Mektup, hatıra ve benzeri yazıların yayımlanabilmesi için, yetkili kişilerin, muvafakat verme süreleri içinde muvafakat vermeleri gerekir. Muvafakat verilmiş olmaksızın mektup, hatıra ve benzeri yazılar yayımlanmışsa, bu durum hukuka aykırılık teşkil eder ve yazıları yayımlayan kişiler hakkında, Borçlar Kanununun manevi tazminata ilişkin 49. maddesi ve Türk Ceza Kanununun sırrın masuniyeti aleyhinde cürümlerine ilişkin 197. ve 199. maddeleri uygulanır (FSEK m.86/III). Ayrica, mektup, hatıra ve benzeri yazıların yayımlanmasina muvafakat edilmiş olsa bile, yayım, yazarı veya muhatabı küçük düşürecek, rencide edecek tarzda yapılmışsa, yayımlayan kişilere karşı, Medeni Kanunun kişilik haklarına saldırıda bulunulması durumunda açılacak davalara ilişkin 24. (ve 25.) maddesi uygulanır (FSEK $\mathrm{m} .86 / \mathrm{IV}$ ).

\section{E - Koruma Süresi}

Mektup, hatıra ve benzeri yazılar üzerindeki yazarın kişilik hakkının korunmasının süresi, FSEK'nda 'bunların yayımlanması için muvafakat verme süresi' olarak düzenlenmiștir ${ }^{50}$.

\section{RESIM VE PORTRELER}

\section{A - Genel Olarak}

FSEK m.86' da 'Resim ve portreler' başlığı altında, 'eser mahiyetinde olmasalar bile, resim ve portreler, tasvir edilenin, tasvir edilen ölmüşse $19 /$ 'de sayılanların muvafakati olmadan tasvir edilenin ölümünden 10 yıl geçmedikçe, teşhir veya diğer suretlerle umuma arz edilemeyeceği' düzenlenmiştir. Bu düzenleme, 'kişiliğin korunması ilkesine' dayanmaktadır. Kişinin resim veya portresi, onu tanıtmaya hizmet eden ve onun kişiliğini dış

\footnotetext{
${ }^{50}$ Muvafakat verme süresine ilişkin olarak bkz. yuk. IV - C - 2 .
} 
dünyaya yansıtan en önemli araçlardan biridir. Kişinin kendi dış görüntüsü kadar, bu görüntünün yansıma ve tekrarını sağlayan vasıtaları, yani resim ve portreleri üzerinde de 'kişilik hakkı' vardır. Dolayısıyla FSEK m.86'da korunan kişi tasvir edilen; korunan hak ise tasvir edilenin kişilik hakkıdır" ${ }^{51}$.

\section{B - Koruma Konusu}

FSEK m.86'da 'resim ve portreler' korunmuştur. Öğretide, FSEK m.86 kapsamındaki resim ve portrelerin; eser niteliğinde olmasalar bile, gerçek bir kişinin, dış görünüşünü teşhis etmeye elverecek biçimde aksettiren, yağlı ve sulu boya, pastel yahut karakalem resimlerini, karikatür, film ve fotoğraflarını ve diğer tüm vasıtaları kapsadığı ifade edilmektedir ${ }^{52}$. Diğer vasitaların kapsamına taş, alçı, bronz vb. büstlerin ${ }^{53}$, ölü maskelerinin ${ }^{54}$, heykellerin $^{55}$ ve şahsı sahnede canlandıran sözlü ve sözsüz temsil ve taklitlerin $^{56}$ gireceği ileri sürülmüştür.

Öğretide yapılan tanımların 1 şı̆̆ında, FSEK m.86 kapsamındaki resim ve portrelerin belli unsurlardan oluştuğu söylenebilir:

1. Tasvir edilen 'gerçek kişi' olmalıdır. FSEK m.86'da korunmak istenen tasvir edilenin kişilik hakkı olduğuna göre; tasvir edilen şey, kişinin kendisi değil, fakat kişinin mal varlığına dahil menkul veya gayrı menkul bir mal ise, bu durumda yapılan tasvir FSEK m.86 kapsaminda 'resim ve portre' kavramına girmez. Sözgelimi, (A)'nın sahip olduğu buldog cins bir köpeğin resmini (B) çekmiş, kartpostal biçiminde basarak dağıtımış ve bundan maddi bir menfaat sağlamışsa, burada FSEK m.86 uygulanmaz. Çünkü, tasvir edilen kişinin kendisi değil, sahip olduğu bir varlıktır.

2. Tasvir edilenin 'dış görünüişü' resmedilmelidir. FSEK m.86 kapsamına sadece gerçek kişilerin dış görüntülerinin yapıldığı tasvirler girer. Dolayısıyla, gerçek kişilerin örneğin hastanede çektirdikleri göğüs, baş, ayak vs. filmleri, 'resim ve portre' kavramına girmez ve FSEK m.86 kapsamında düşünülemez. Dış görüntünün, hangi cepheden alındığının veya hangi araç kullanıldığının, tasvirin 'resim ve portre' kavramına girip girmemesi açısından bir önemi yoktur. Tasvir edilenin dış görünüşünün, resimde ikinci planda kalıp kalmaması ve eğer ikinci planda kalıyorsa, tasvir edilenin FSEK

\footnotetext{
51 ARSLANLI, age, s. 58; BELGESAY, age, s. 148; YARSUVAT, age, s. 72; ÖZSUNAY, Ergun: Gerçek Kişilerin Hukuki Durumu, İstanbul, 1979. s. 98; AYITER, age, s. 82; EREL, age, s. 190.

52 ARSLANLI, age, s. 59; BELGESAY, age, s. 148; YARSUVAT, age, s. 72; GÜMÜŞ, Mustafa Alper: "Kişinin Resmi (Görünümüi) Üzerindeki Hakkı”, Kocaeli Üniversitesi Hukuk Fakültesi Dergisi, Kastm 1997, Y. 1, S. 1, s. 364; EREL, age, s. 190; TEKINALP, age, s. 274.

${ }^{5.3}$ ARSLANLI, age, s. 59; AYITTER, age, s. 82.

${ }^{5.4}$ AYITER, age, s. 82.

${ }^{55}$ BELGESAY, age, s. 148.

${ }^{56}$ ARSLANLI, age, s. 59.
} 
m.86'da kendisine tanınan haktan yararlanıp yararlanmayacağı konusu tartışmaya açıktır. Öğretide, belli bir yerin fotoğrafı çekilirken tesadüfen başka bir kimse de resme dahil olmuşsa, diğer bir deyişle kişinin ayrınt olarak fotoğrafa dahil olduğu durumlarda, fotoğrafın umuma arzı için FSEK m.86'da öngörülen muvafakatin alınmasına gerek olmadığı ileri sürülmektedir. Sözgelimi tarihi bir anıtın resmi alınırken orada bulunanların da görüntülerinin fotoğraf içinde kalmaları halinde, fotoğrafta bulunan herkesten muvafakat alınmasina gerek yoktur ${ }^{57}$. Yargitay, bu durumda bile çekilen fotoğrafın ticari ve reklam amacıyla kullanılamayacağını ileri sürerek tasvir edilen kişinin açtığı manevi tazminat davasını kabul etmiştir ${ }^{58}$.

3. Yapılan tasvir, tasvir edileni teşhise imkan vermelidir. Tasvirin 'resim ve portre' kavramı içine girebilmesi ve FSEK m.86 hükmü çerçevesinde tasvir edilenin korunabilmesi için, tasvirin tasvir edilen kişiye ne kadar benzediği önemli değildir. Olağan bir inceleme ve dikkat sonucu tasvir edilenle bir bağlantı kurulabiliyorsa, bu durum tasviri 'resim ve portre' kapsamı içine sokmak ve tasvir edilenin kişilik hakkını korumak için yeterlidir ${ }^{59}$. Olağan bir incelemenin nasıl yapılacağı $\mathrm{MK}$ m.2'deki objektif iyiniyet kuralları çerçevesinde değerlendirilmelidir. Tasvire; orta zekalı, makul bir kişinin nazarıyla bakılarak sonuca ulaşılmalıdır. Bu bağlamda kanaatimce kişinin sadece bir uzvunun resmedilmesi de koruma kapsamına girebilmelidir. Fakat, burada uzvu gösteren resimden olağan bir inceleme ve dikkat sonucu belirli bir kişiye ait olduğu sonucu çıkartılabiliyorsa, kişilik hakkının korunması mümkün olabilir. Örneğin AIDS'li bir hastanın kollarındaki yaraların resmedilmesinde, eğer hastanın kim olduğu olağan bir inceleme sonucu anlaşılabiliyorsa FSEK m.86 kapsamında hastadan muvafakat alınmadan teşhir ve umuma arz edilememesi gerekir.

4. Resim ve portrelerin eser niteliğinde olması gerekli değildir. Tasvirin 'resim ve portre' kavramma girebilmesi ve tasvir edilenin kişilik hakkının korunması; öncelikle bunların eser niteliği taşımasına bağlı değildir. Diğger deyişle, resim ve portreler eser niteliği taşımasalar bile FSEK m.86 kapsamında korumaya dahildir. FSEK m.86, "hususiyet taşımayan alelâde resimler' ile 'eser niteliğinde hususiyeti haiz resimler' arasında,

\footnotetext{
${ }^{57}$ YARSUVAT, age, s. 73; ÖZSUNAY, age, s. 98.

${ }^{5 *}$ HGK. 3.10.1990, E. 1990/4-275, K.1990/459: "Davaya konu işte davacılara ait ve Anıtkabir içinde çekilmiş resim davalıya ait derginin reklamlarında kullanılmıştır. Kullanılmanın izinsiz ve ticari amaçla olduğu tartışmasızdır. FSEK m.86'da açıkça 'resim ve portrelerin izinsiz yayınlanması' yasaklanmıştır. Bu nedenle sorumluluk için resim çckmenin amacı önemli değildir. Davacıların dış görünüşleri resimde yer aldığına göre eylemin yasanın emredici kuralına açıkça aykırı olduğu kabul edilmelidir. Davacıların dış görünüşlerinin resim için ikinci planda kalıp kalmaması da önemli değildir. Asıl olan kişinin dış görünüşünün yayınlanan resimde yer almış olmasıdır." (YKD, Nisan 1991, C. 17, S. 4, s. 522).

5i) HIRSCH, Fikri Haklar, s. 138; ARSLANLI, age, s. 59; BELGESAY, age, s. 148; EREL, agc, s. 190.
} 
koruma bakımından fark gözetmemiştir. Dolayısıyla, resim veya portre eser niteliğinde ise, eser niteliğindeki resim veya portrenin yaratıcısının (sanatçının) mutlak hakkı, bu halde tasvir edilenin kişilik hakkına üstünlük taşımamaktadır. Kişinin resmi üzerindeki kişilik hakkı, eser sahibinin eseri üzerindeki haktan daha üstün tutulmuştur ${ }^{6(t)} . \mathrm{Bu}$ durum, öğretide eleştirilmiştir. Eser niteliğindeki resim ve portreler üzerinde sadece tasvir edilenin değil, eseri vücuda getiren sanatçının ve eseri satın almış olan kişinin de hakları vardır. Tasvir edilenin kişilik hakkı nasıl bir mutlak hak ise, sanatçının fikri hakları ve satın alanın mülkiyet hakkı da aynı şekilde mutlak haklardır ve bunlardan birinin diğerine tercihi için makul bir neden yoktur. Bu nedenle, tasvir edilenin kişilik haklarına üstünlük tanıyan bu düzenleme yerine, çeşitli hakların bağdaştırılmasını sağlayacak bir düzenlemenin daha uygun olacağg ileri sürülmüştür ${ }^{6 !}$.

\section{C - Koruma Koşulları}

Resim ve portrelere ilişkin FSEK m.86/III-IV'de düzenlenen koruma hükümlerinin uygulanabilmesi için, 'bunların umuma arz edilmesine muvafakat verilmemiş olması', 'muvafakat verme süresinin geçmemiş olması' ve 'muvafakat verilmesine gerek olmayan durumların bulunmaması' koşullarının birlikte gerçekleşmiş olması gerekir.

\section{Muvafakat Verilmemiş Olması}

FSEK m.86/I'e göre, resim ve portrenin umuma arzı için yetkili kişilerin muvafakati gerekmektedir. Tasvir edilenin veya diğer yetkili kişilerin, FSEK m.86/III'de düzenlenen koruma hükümlerinden yararlanabilmeleri için, muvafakatin verilmemiş olması gerekir.

Muvafakat; tek taraflı bir hukuki işlem olup, varması gerekli bir irade beyanı ile hukuki sonuç yaratır. Muvafakat, ivazlı veya ivazsız olabilir. Tasvir edilen, resim veya portresinin umuma arzı için, umuma arz edecek kişiden ivaz almış olabilir. Resim veya portrenin umuma arzı karşılığında tasvir edilene ivaz verilmişse, uyuşmazlık halinde taraflar arasındaki sözleşme hükümleri öncelikle uygulanır. İvaz alınması, resim ve portre üzerindeki kişilik hakkının devri anlamına gelmez ${ }^{62}$.

Muvafakat, yazılı veya sözlü verilebilir. FSEK m.86'da muvafakatin yazılı olma koşulu zikredilmediğinden, sözlü olarak verilmesinde hukuken sakınca yoktur. Muvafakat, açı (sarih) olabileceği gibi örtülü (zımnî) de olabilir. Örnek olarak ücret karşılığında poz veren foto modellerin veya mankenlerin, bu resimlerin yayımlanmasına da zımnen muvafakat ettikleri öğretide ileri sürülmüştür. Zira çekilen resmin yayımlanması, foto modellik veya mankenlik mesleklerinin bir gereğidir. Bu kişiler çektirdikleri resmin

\footnotetext{
${ }^{6}$ YARSUVAT, age, s. 72.

${ }^{61}$ AYITER, age, s. 82-83; EREL, age, s. 190.

62 ÖZTAN, Bilge: Şahsın Hukuku-Hakiki Şahıslar, Ankara, 1990, s. 128
} 
umuma arz edileceğini bilerek hatta isteyerek resim çektirmektedirler. Dolayısıyla bu kişiler için özel bir muvafakat aramaya gerek yoktur, muvafakatin baştan itibaren zımnen var olduğu kabul edilir ${ }^{6.3}$.

Kural olarak, muvafakat vermeye yetkili kişi, tasvir edilen kişi yaşıyorsa, tasvir edilen kişinin kendisidir ${ }^{64}$. Tasvir edilen kişi ölmüşse, FSEK m.86/I uyarmca, FSEK m.19/I'de sayılan kişilerin muvafakati gerekir ${ }^{65}$. Muvafakatin kapsamını tayin yetkisi de tasvir edilende veya tasvir edilen ölmüşse yetkili mirasçılardadır. Resim ve portrelerin teşhir veya diğer yollardan kamuya sunulması hususunda, tasvir edilen kimsenin takdir yetkisi vardır. Resim yada portrenin umuma arzı, açıklanan muvafakatin çerçevesini aşmamalıdır ${ }^{160}$.

\section{Muvafakat Verme Süresinin Geçmemiş Olması}

FSEK $m .86 / \mathrm{I}$ bu durumda tasvir edilenin muvafakat verme yetkisini süre bakımından sınırlamamıştır. Dolayısıyla tasvir edilen hayatta iken muvafakat verme süresi işlemez. Tasvir edilen kişi ölmüsse, muvafakat vermeye yetkili kişiler, bu yetkilerini tasvir edilenin ölümünden sonra 10 yıl içinde kullanabilirler (FSEK m.86/I). Tasvir edilenin ölümünden sonra 10 y1l geçmişse, resim ve portre, hiç kimsenin muvafakatine gerek kalmadan teşhir ve umuma arz edilebilir.

\section{Muvafakat Alınmasına Gerek Olmayan Durumlarin Bulunmaması}

Kanun koyucu, güncel olaylarla ilişkili olan bazı resim ve portreler üzerindeki hakları, kamu yararına ve kamunun haber alma özgürlüğünü sağlamak amacıyla sınırlandırılmıs ve kanunda öngörülen bazı durumlarda tasvir edilenden muvafakat alınması gerekmeden, resim ve portrelerin umuma arz edilebileceğgi kabul etmiştir ${ }^{67}$.

Muvafakat verilmesine gerek olmayan durumlar, FSEK m.86/II-1,2,3 ve FSEK m.30'da düzenlenmiştir.

a) FSEK m.86/II-I'e göre; memleketin siyasal ve sosyal hayatında rol oynayan kimselerin: meselâ, siyasi parti başkanları, senatör, milletvekilleri

\footnotetext{
ar ARSL ANLI. age. s. 59; YARSUVAT, agc, s. 73; GÜMÜŞ, agm, s. 380; EREL, age.s. 191.

${ }^{\text {on }}$ BEI GESAY a göre, bazı durumlarda, tasvir edilenin resim ve portresini umuma arz için muvafakat vermesi yetkisine, kişinin eşi de sahip olmalıdır. Şöyle ki, karı veya koca. eşinin resminin teşhiri kendini hacalete (utanca) maruz bırakırsa onun teşhire muvafakatinin hükümsüz sayılnası içn yargıcın müdahalesini istemelidir. Bir anlamda eşini hacalete maru\% bırakacak bir şeye izin veren kan veya koca, onun kişilik hakkma tecavüz etmiş olur. Bkz: BELGESAY, a@e. $s .149$.

${ }^{65}$ FSEK m. 19/I'de ya\%lan kişilere ilişkin olarak bkz. yuk. IV - C - 1

(x) ÖZTAN, age, s. 128; GÜMÜŞ, agm, s. 380-381.

6.7 AYITER, age, s. 83-84; EREL, age, s. 191.
} 
veya sinema oyuncuları gibi kimselerin resimleri, muvafakatleri alınmadan yayımlanabilir. BELGESAY, bu fıkrada bahsi geçen kişileri 'faaliyetleri halkı alâkalandıran kişiler ${ }^{\prime \prime}$ olarak, ÖZSUNAY ise, 'kamunun ilgisini çeken ve toplumda tanınmış olan (public figure) kişiler ${ }^{69}$ olarak ifade etmektedir. Esasen bu kişilerin resimlerinin her umuma arzında muvafakat alınması yoluna gidilseydi, basın haber verme görevini yerine getiremeyecekti. Ayrıca bu kişilerin resimlerinin umuma arz edilmesinde, kendilerinin de menfaati bulunmaktadır.

b) FSEK m.86/II-2'ye göre; geçit töreninde veya resmi bir törende ya da genel bir toplantıda görülen kimselerin resimleri izin alınmadan yayımlanabilir. Bu gibi resimlerin amacı belli bir kimseyi göstermekten başka, olayın saptanması ve nakledilmesidir ${ }^{70}$.

c) FSEK m.86/II-3'e göre, günlük hadiselere müteallik resimlerle radyo ve film haberleri için de muvafakat alınması koşulu aranmamıştır. Madde metninin 'günlük hadiselere ilişkin haberlerde kullanlan resimler' biçiminde değiştirilmesi yerinde olur.

d) FSEK m.30'a göre, umumi emniyet mülahazasıyla ve adli maksatlar için yayımlanan resimler için de, muvafakat verilmesi koşulu aranmamıştır. Mesela, bir suçlunun resmi savcılığın emriyle gazete ve televizyon vasıtasıyla yayımlanabilecektir ${ }^{71}$.

Ancak muvafakatin aranmadığı bu durumlarda bile, resmi veya portreyi umuma arz eden kişilerin uymaları gereken kriterler vardır. Her şeyden önce söz konusu durumlarda resim yada portrenin yayımlanması için 'sosyal uygunluğun' bulunması gerekir ${ }^{72}$. Sosyal uygunluk, özel hayata ilişkin yayımların, özel hayatın gizliliğinden daha önde gelen haklı bir menfaate hizmet ettiği zaman mevcuttur ${ }^{73}$. Resim haber verme amacını aşıp özel hayata tecavüz mahiyetini taşıyorsa veya olayı yansıtma dışında, siyasi veya ticari amaçlarla kullanılıyorsa hukuka aykırıdır ${ }^{74}$. Burada esasen bir çıkarlar dengelemesi söz konusudur. Bu denge, halkın, toplumsal yaşam bakımından önemli olayları öğrenme hakkı ile kişinin genel olarak kişilik hakkı ve özel olarak da, resmi üzerindeki hakkı arasında kurulacaktır ${ }^{75}$.

\footnotetext{
${ }^{68}$ BELGESAY, age, s. 150.

(9) ÖZSUNAY, age, s. 99.

${ }^{77}$ ARSLANLI, age, s. 59; YARSUVAT, age, s. 74.

$"$ ARSLANLI, age, s. 60; EREL, age, s. 191

${ }^{72}$ ÖZSUNAY, age, s. 147; DURAL, Mustafa: Türk Medeni Hukukunda Gerçek Kişiler, İstanbul, 1984, s. 510; ÖZTAN, age, s. 129.

${ }^{73}$ DURAL, age, s. 148, 150; ÖZTAN, age, s. 128; GÜMÜŞ, agm, s. 382-384.

${ }^{74}$ AYITER, age, s. 84; DURAL, age, s. 151; ÖZTAN, age, s. 129.

${ }^{75}$ ÖZSUNAY, age, s. 99.
} 


\section{D - Koruma Hükümleri}

Resim ve portrenin teşhir ve umuma arz edilebilmesi için, yetkili kişilerin, muvafakat gerektiren durumlarda muvafakat verme süreleri içinde muvafakat vermeleri gerekir. Muvafakat olmaksızın resim ve portre üçüncü kişilerce umuma arz edilmişse, bu durum hukuka aykırılık teşkil eder. Bu durumda resim ve portreyi muvafakat olmadan umuma arz eden kişiler hakkında, Borçlar Kanununun manevi tazminata ilişkin 49. maddesi ve Türk Ceza Kanununun sırrın masuniyeti aleyhinde cürümlerine ilişkin 197. ve 199. maddeleri uygulanır (FSEK m.87/III). Ayrıca, resim ve portrenin umuma arz edilmesine muvafakat verilmiş olsa bile, umuma arz, tasvir edileni, küçük düşürecek, rencide edecek tarzda yapılmışsa, yayımlayan kişilere karşı, Medeni Kanunun kişilik haklarına saldırıda bulunulması durumunda açılacak davalara ilişkin 24. (ve 25.) maddesi uygulanır (FSEK m.87/IV).

\section{E - Koruma Süresi}

Resim ve portreler üzerindeki tasvir edilenin kişilik hakkının korunmasının süresi, FSEK'nda 'teşhir ve umuma arz için muvafakat verme süresi' olarak düzenlenmiştir ${ }^{76}$.

\section{SONUÇ}

FSEK m.83-87 arasında yer alan 'eser dışındaki koruma konularının' iki ilkeden hareket edilerek düzenlendiği görülmektedir. Bu ilkeler, haksız rekabet yasağı ilkesi ve kişiliğin korunması ilkesidir. 'Bir eserin adı, alâmetleri ve çoğaltılmış nüshalarının şekilleri' ile 'işaret, resim veya ses nakline yarayan araçların' korunması haksız rekabet yasağı ilkesinin; 'mektup, hatıra ve benzeri yazılar' ile 'resim ve portrelerin' korunması da kişiliğin korunması ilkesinin özel bir uygulamasıdır. Dolayısıyla Fikir ve Sanat Eserleri Kanunu'ndaki eser dışındaki koruma konularına yönelik hükümler; Medeni Kanun, Borçlar Kanunu ve Türk Ticaret Kanunu'ndaki kişiliğin korunmasına ve haksız rekabete ilişkin hükümlerin birer uygulama biçimi olarak gözükmektedir.

\footnotetext{
${ }^{7 h}$ Muvafakat verme süresine ilişkin olarak bkz. yuk. V $-C-2$.
} 


\section{KAYNAKÇA}

ARKAN, Sabih: Tican̂ İşletme Hukuku, 6. Baskı, Ankara, 2001.

ARSLANLI, Halil: Fikrî Hukuk Dersleri II, Fikir ve Sanat Eserleri, İstanbul, 1954. 1981.

AYITER, Nuşin: Hukukta Fikir ve San'at Ürünleri, 2. Bası, Ankara,

BELGESAY, M. Reșit: Fikir ve Sanat Eserleri Kanunu Şerhi, İstanbul, 1955.

BEŞİROĞLU, Akın: Düşünce Ürünleri Üzerindeki Haklar, Fikir Hukuku, Birinci Cilt, Temel Kurallar, 2. Bası, Ankara, 2002. 1984.

DURAL, Mustafa : Türk Medeni Hukukunda Gerçek Kişiler, İstanbul,

EREL, Şafak N.: Türk Fikir ve Sanat Hukuku, 2. Bası, Ankara, 1998.

GÜMÜŞ, Mustafa Alper: "Kişinin Resmi (Görünümü) Üzerindeki Hakkı", Kocaeli Üniversitesi Hukuk Fakültesi Dergisi, Kasım 1997, Y. 1, S. 1, s. 363-386.

HIRSCH, Ernst E.: Hukuki Bakımdan Fikrî Sây, İkinci Cilt, Fikri Haklar (Telif Hukuku), İstanbul, 1943 (Anılış: Fikrî Sây). Haklar).

HIRSCH, Ernst E.: Fikrî ve Sınaî Haklar, Ankara, 1948 (Anılış: Fikrî

ÖZSUNAY, Ergun: Gerçek Kişilerin Hukuki Durumu, İstanbul, 1979.

ÖZTAN, Bilge: Şahsın Hukuku-Hakiki Şahıslar, Ankara, 1990.

TEKİNALP, Ünal: Fikrî Mülkiyet Hukuku, İstanbul, 1999.

YARSUVAT, Duygun: Türk Hukukunda Eser Sahibi ve Hakları, İstanbul, 1977.

YILMAZ, Ejder: Hukuk Sözlüğü, 4. Baskı, Ankara, 1992. 